\title{
Multivariate predictive model of minerals content in the basal portion of peach palm heart (Bactris gasipaes Kunth) using agrometeorological data
}

\section{Modelo preditivo multivariado do conteúdo mineral na porção basal de pupunha utilizando dados agrometeorológicos}

\author{
Marcelo Barba Bellettini ${ }^{*}$; Fabiane Bach²; Miriam Fabiola Fabela Morón ${ }^{3}$; \\ João Carlos Bespalhok Filho ${ }^{4}$
}

\begin{abstract}
The climatic influence in minerals content of peach palm heart (Bactris gasipaes Kunth) was studied and a quick method was assessed to determine $\mathrm{Mg}, \mathrm{Cl}, \mathrm{K}$ and $\mathrm{S}$ in the basal portion of peach palm heart based on multivariate predictive model using agro-meteorological data. A total of 24 samples of B. gasipaes Kunth were collected along 14 to 18 months of cultivation, growing in two types of terrain: hillside and lowland. Principal component analysis (PCA) was used to select principal components. The data were modeled using partial least squares regression (PLS). Low average relative prediction errors $(4.60 \%)$ confirm the good predictability of the models. The factors that most influence the minerals content prediction model were the rain precipitation and solar radiation. The results show that predictive model can be used as rapid method to determine the mineral content in the basal portion of peach palm heart factories and may help to choose geographical regions suitable for the establishment of new peach palm plantations. The models can provide reductions of cost and time analysis to palm heart without generating laboratory effluents. This is the first time in which multivariate analysis is used to generate models to predict minerals concentration in the basal portion of peach palm hearts, quantifying numerically the intensity of climatic factors in the minerals content.
\end{abstract}

Key words: Peach palm. Mineral content. Agro-meteorological factors. Multivariate statistical analysis. Climatic influence.

\section{Resumo}

A influência climática em minerais de pupunheira (Bactris gasipaes Kunth) foi estudada e um método rápido foi avaliado para determinar $\mathrm{Mg}, \mathrm{Cl}, \mathrm{K} \mathrm{e} \mathrm{S}$ na porção basal de palmito de pupunha baseado no modelo preditivo multivariado utilizando dados agro-meteorológicos. Um total de 24 amostras de $B$. gasipaes Kunth foram coletadas ao longo de 14 a 18 meses de cultivo, cultivados em dois tipos de terreno: encosta e baixada. A análise de componentes principais (PCA) foi utilizada para seleccionar as componentes principais. Os dados foram modelados utilizando o método de regressão por mínimos

\footnotetext{
1 Pós-Doutorando em Agronomia, Produção Vegetal, Departamento de Agronomia, Universidade Federal do Paraná, UFPR, Curitiba, PR, Brasil. E-mail: marcelobeletini@yahoo.com.br

2 Prof $^{\mathrm{a}}$ Dr$^{\mathrm{a}}$, Departamento de Engenharia de Alimentos, Universidade Estadual de Mato Grosso do Sul, UEMS, Naviraí, MS, Brasil. E-mail: fabi.b.eng@hotmail.com

3 Prof $^{a}$ Dra $^{\text {a }}$, Departamento de Tecnología Alimentar, Centro de Investigación y Asistencia en Tecnología y Diseño del Estado de Jalisco, CIATEJ, Mérida, YUC, México. E-mail: qa.miriamfabela@gmail.com

4 Prof. Dr., Departamento de Fitotecnia, UFPR, Curitiba, PR, Brasil. E-mail: bespa@ufpr.br

* Author for correspondence
} 
quadrados parciais (PLS). Baixos erros relativos médios de previsão (4,60\%) confirmam a boa previsibilidade dos modelos. Os fatores que mais influenciaram o modelo de previsão de minerais foram a precipitação pluviométrica e a radiação solar. Os resultados mostram que o modelo preditivo pode ser usado como um método rápido para determinar o conteúdo mineral em indústrias de palmito pupunha, podendo ajudar na escolha de regiões geográficas adequadas para o estabelecimento de área de plantios de pupunha. Os modelos podem fornecer reduções de custo e análise de tempo para a indústria de palmito sem gerar efluentes de laboratório. Esta é a primeira vez em que a análise multivariada é utilizada para gerar modelos para predizer a concentração de minerais na porção basal de pupunha, quantificando numericamente a intensidade de fatores climáticos no conteúdo mineral.

Palavras-chave: Pupunha. Minerais. Fatores agro-meteorológicos. Análise estatística multivariada. Influência climática.

\section{Introduction}

Brazil is the world's main producer and consumer of palm heart (PENTEADO JÚNIOR et al., 2014). Most palm heart is illegally obtained from wildlygrown Euterpe oleracea Mart. and E. edulis Mart. plants, which has threatened the survival of both species (BATAGIN-PIOTTO et al., 2012). In recent years, however, extractivism has been giving way to more rational forms of exploitation, such as sustained management. In this context, peach palm (Bactris gasipaes Kunth) emerges on the market because it is profitable because of its tillering capacity, that is, the ability to emit new branches from the cut of the parent plant and by the rapid development in 2 years of cultivation, while other palms of the Euterpe genus require 6 to 8 years of cultivation (HERNÁNDEZ-UGALDE et al., 2011). The pupunha is also sustainable, allowing consumption of a product of good quality and traceability, being an alternative against the clandestine cut of the juçara palm heart (KULCHETSCKI et al., 2001).

Peach palm consists of three parts: caulinar (basal), of larger diameter, located in the lowest region of the stem of the palm heart; apical, leaflike and with reduced diameter, located at the apex of the thallus; and, cream, heart or tolete, located between the basal and apical parts. The basal or caulinar portion has a larger diameter, it is located in the lower region of the stem of the heart of palm. It is composed of the soft part of the stem and, on average, weighs about 120 to $300 \mathrm{~g}$, and can reach up to $800 \mathrm{~g}$ or more; its length varies from 10 to 25 cm (RAUPP; CHAIMSOHN, 2001). It is an edible, slightly sweet, cylindrical and tender product; rich in amino acids, fiber, minerals and vitamins, besides being low in calories (GALDINO; CLEMENTE, 2008).

B. gasipaes is a species that has been implanted in diverse climatic conditions, presenting good adaptation (NEVES; SANTOS, 2008). However, it requires sufficient temperature, humidity and light, in which the ideal conditions are the hot and humid climate regions, with annual mean temperature above $21{ }^{\circ} \mathrm{C}$ and precipitation above $2000 \mathrm{~mm}$ year $^{-1}$ well distributed. According to the authors, development of peach palm depends more on climate than on soil conditions.

There have been significant research efforts predicting the effect that the climate it has on peach palm production systems in the tropics (NEVES et al., 2007). However, the intensity of climatic factors in the basal portion of pupunha culture has not yet been quantified. Also, there is still very little evidence that the observed changes and variability in climate patterns over recent decades have already impacted peach palm heart production globally and particularly in Brazil.

According to a recent survey of literature, to date no research has been reported using multivariate calibration for the determination of mineral content in the basal portion of peach palm, which is relevant considering that this analysis can be inserted into 
the industrial production allowing important conclusions about the use of basal portion of peach palm heart. Within this context, the aim of the work is to evaluate the potential of agrometeorological factors combined with chemometrics in order to quantify the minerals concentration in samples of basal portion in peach palm heart. Since the traditional mineral analysis of peach palm hearts typically presents low repeatability and generate large amounts of waste, the use of an alternative method for minerals content prediction, which does not involve sample preparation, can presents a series of advantages, including cost and processing time reduction and elimination of chemical waste. In this paper, we describe the use of principal component analysis, along with partial least squares regression, to generate predictive models for the minerals content in the basal portion of peach palm hearts, quantifying numerically the intensity of the climate in the minerals concentration.

\section{Materials and Methods}

\section{Plant material}

The harvest site is located on the side of Alexandra - Matinhos Road, km 12, at Paranaguá, State of Paraná, Brazil, coordinates 2509'19, 2" S and $48^{\circ} 35^{\prime} 15,0$ ' W. The soil is a Haplic Cambisol of medium texture. In its results soil the layer of 0 $20 \mathrm{~cm}$ presented: $\mathrm{pH}, 5.30\left(\mathrm{CaCl}_{2}\right) ; \mathrm{Al}^{3+}, 0.00 ; \mathrm{H}^{+}+$ $\mathrm{Al}^{3+}$ (extractable acidity), $4.30 \mathrm{cmol}_{\mathrm{c}} \mathrm{dm}^{-3} ; \mathrm{Ca}^{2+}, 3.00$ $\mathrm{cmol}_{\mathrm{c}} \mathrm{dm}^{-3} ; \mathrm{Mg}^{2+}, 1.30 \mathrm{cmol}_{\mathrm{c}} \mathrm{dm}^{-3} ; \mathrm{K}^{+}, 0.14 \mathrm{cmol}_{\mathrm{c}}$ $\mathrm{dm}^{-3}$; SB (sum of bases), $4.44 \mathrm{cmol}_{\mathrm{c}} \mathrm{dm}^{-3}$; T (cation exchange capacity), $8.74 \mathrm{cmol}_{\mathrm{c}} \mathrm{dm}^{-3} ; \mathrm{P}, 25.90 \mathrm{mg}$ $\mathrm{dm}^{-3} ; \mathrm{C}, 8.1 \mathrm{mg} \mathrm{dm}^{-3} ; \mathrm{OM}$ (organic matter), $13.96 \mathrm{mg}$ $\mathrm{dm}^{-3}$. In soil layer of $20-40 \mathrm{~cm}$ presented: $\mathrm{pH}, 5.50$ $\left(\mathrm{CaCl}_{2}\right) ; \mathrm{Al}^{3+}, 0.00 ; \mathrm{H}^{+}+\mathrm{Al}^{3+}, 3.40 \mathrm{cmol}_{\mathrm{c}} \mathrm{dm}^{-3} ; \mathrm{Ca}^{2+}$, $2.20 \mathrm{cmol}_{\mathrm{c}} \mathrm{dm}^{-3} ; \mathrm{Mg}^{2+}, 1.20 \mathrm{cmol}_{\mathrm{c}} \mathrm{dm}^{-3} ; \mathrm{K}^{+}, 0.07$ $\mathrm{cmol}_{\mathrm{c}} \mathrm{dm}^{-3} ; \mathrm{SB}, 3.47 \mathrm{cmol}_{\mathrm{c}} \mathrm{dm}^{-3} ; \mathrm{T}, 6.87 \mathrm{cmol}_{\mathrm{c}} \mathrm{dm}^{-3}$; $\mathrm{P}, 5.60 \mathrm{mg} \mathrm{dm}^{-3}$; C, $3.1 \mathrm{mg} \mathrm{dm}^{-3}$; OM, $5.34 \mathrm{mg} \mathrm{dm}^{-3}$. The climate is classified as an Af Tropical Superwet with no water deficit, average temperatures over of
$22{ }^{\circ} \mathrm{C}$ in the warmest month, and over $18{ }^{\circ} \mathrm{C}$ in the coldest (average annual temperature of $22.80 \pm 3.14$ $\left.{ }^{\circ} \mathrm{C}\right)$. The annual average relative humidity is within the $80-90 \%$ range, while rainfall averages $2500-$ $3000 \mathrm{~mm}$ annually (EMBRAPA, 2013).

Peach palm hearts were collected from plants aged between 14 and 18 months, between January and December 2016. Plants were grown in two different types of terrain: hillside (average slope of 20 degrees) and lowland (average slope lower than 2 degrees). After harvest, the peach palm heart samples were separated, using of a stainless steel knife, for minerals content analysis.

\section{Mineral determination}

Samples were reduced to ash at $580-600{ }^{\circ} \mathrm{C}$ for approximately $12 \mathrm{~h}$. The ash was solubilized in nitric acid (1N), heated on a plate for 2 - 3 minutes and transferred to volumetric balloons, with the final volume of $100 \mathrm{~mL}$ supplemented with nitric acid (AOAC, 2010). Aluminum (Al), calcium (Ca), chlorine $(\mathrm{Cl})$, cobalt $(\mathrm{Co})$, copper $(\mathrm{Cu})$, iron $(\mathrm{Fe})$, magnesium $(\mathrm{Mg})$, manganese $(\mathrm{Mn})$, molybdenum (Mo) and zinc ( $\mathrm{Zn})$ contents were determined through atomic absorption spectrophotometry (968.08). Lanthanum was added to the $\mathrm{Ca}$ and $\mathrm{Mg}$ samples to prevent interferences caused by phosphate ions. Potassium $(\mathrm{K})$ and sodium $(\mathrm{Na})$ were determined through atomic emission spectrophotometry (984.27). Phosphorus (P) was determined by the yellow method molybdenum (966.01). Sulfur (S) was determined by the gravimetric method of barium chloride (turbidimetry) (956.01). Boron (B) was determined by spectrophotometry method azomethine-H (958.03). Readings of these elements were made at the following wavelengths $(\lambda \mathrm{s})$ in $\mathrm{nm}: \lambda \mathrm{Al}=309.3 ; \lambda \mathrm{Ca}=422.7 ; \lambda \mathrm{Cl}=588.0 ; \lambda \mathrm{Co}$ $=240.7 ; \lambda \mathrm{Cu}=324.7 ; \lambda \mathrm{Fe}=248.3 ; \lambda \mathrm{Mg}=285.2$; $\lambda \mathrm{Mn}=279.5 ; \lambda \mathrm{Mo}=313.3 ; \lambda \mathrm{Na}=589.0 ; \lambda \mathrm{Zn}=$ $213.9, \lambda \mathrm{K}=766.5 ; \lambda \mathrm{P}=420.0$ and $\lambda \mathrm{B}=410.0$. 
Agro-meteorological data

Rain precipitation $(\mathrm{mm})$, atmospheric pressure $(\mathrm{hPa})$, solar radiation $\left(\mathrm{W} \mathrm{m}^{-2}\right)$ air temperature $\left({ }^{\circ} \mathrm{C}\right)$. data were obtained from a weather station in the town of Morretes, located $15 \mathrm{Km}$ from the harvest site (Meteorological System of Paraná - SIMEPAR).

\section{Multivariate processing}

A systematic procedure was carried out to study climatic influence in minerals content of peach palm heart (Figure 1). The Origin Pro 8.0 software (Origin Lab., Northampton, MA, USA) was used to construct arrays of data. The data were processed in Matlab version 7.1 (Mathworks Inc.) using the PLStoolbox 1.5 package (Eigenvector Research Inc.) for data analysis. Principal component analysis (PCA) was used to reduce the dimensionality of the data set for the variables and called principal components (PCs), which describe the largest variance of the analysed data (FRIZON et al., 2015). PCA is the most frequently used multivariate method that can be used to classify samples with diverse biological status, origin or quality (CHUNTHABUREE et al., 2016). Two PCAs were used, the first one to evaluate the variation in minerals content along 12 months and the second one for analysing on the basis agro-meteorological factors. The clustering method used was the simple (closest neighbour) method, in which the distance of two groups is given by the smallest of all distances between the objects of two groups. This method establishes more dispersed groups, less sensitive to atypical samples (FERREIRA, 2015). The performance of the PCA was evaluated using root mean square error of cross-validation (RMSECV) and the stabilization of the eigenvalues.
Partial least squares regression (PLS) was utilized to build prediction models for the effect of agro-meteorological factors on minerals content. The calibration group for each mineral consisted of 12 essays, average of growing sites, in two subsets, the calibration set (model building) and the internal validation group. The calibration set $(70 \%$ of the samples) were used for the development of the model (calibration group) and the internal validation group ( $30 \%$ of data), was defined to validate the results (prediction set, validation group), respectively. PLS models were developed to relate the variable $\mathrm{X}$ (minerals concentration, independent variable or predictor) to the variable Y (agro-meteorological data, dependent variable) and to predict the minerals content of the peach palm heart. The prediction set (independent set) was defined to validate the results from the current study. Cross-validation was employed along with the leave-one-out procedure for the set validation, once it does not waste data (all samples are used for the model development) and it also appropriated for a small number of samples (OLIVEIRA et al., 2014). In the cross-validation process, each sample from the calibration set is deleted only once. The process was repeated until all the samples had been used once in the validation set (XIE et al., 2007). Outliers were detected by using leverage criteria and studentized residuals $( \pm 2.5)$, according to: $3 \mathrm{LV}$ $\mathrm{n}^{-1}$, where $\mathrm{n}$ is the number of samples and LV is the number of latent variables. The performance of the PLS models was evaluated using root mean square error of calibration (RMSEC) and the average relative errors. 
Figure 1. Flowchart demonstrating the main steps of the study procedures.

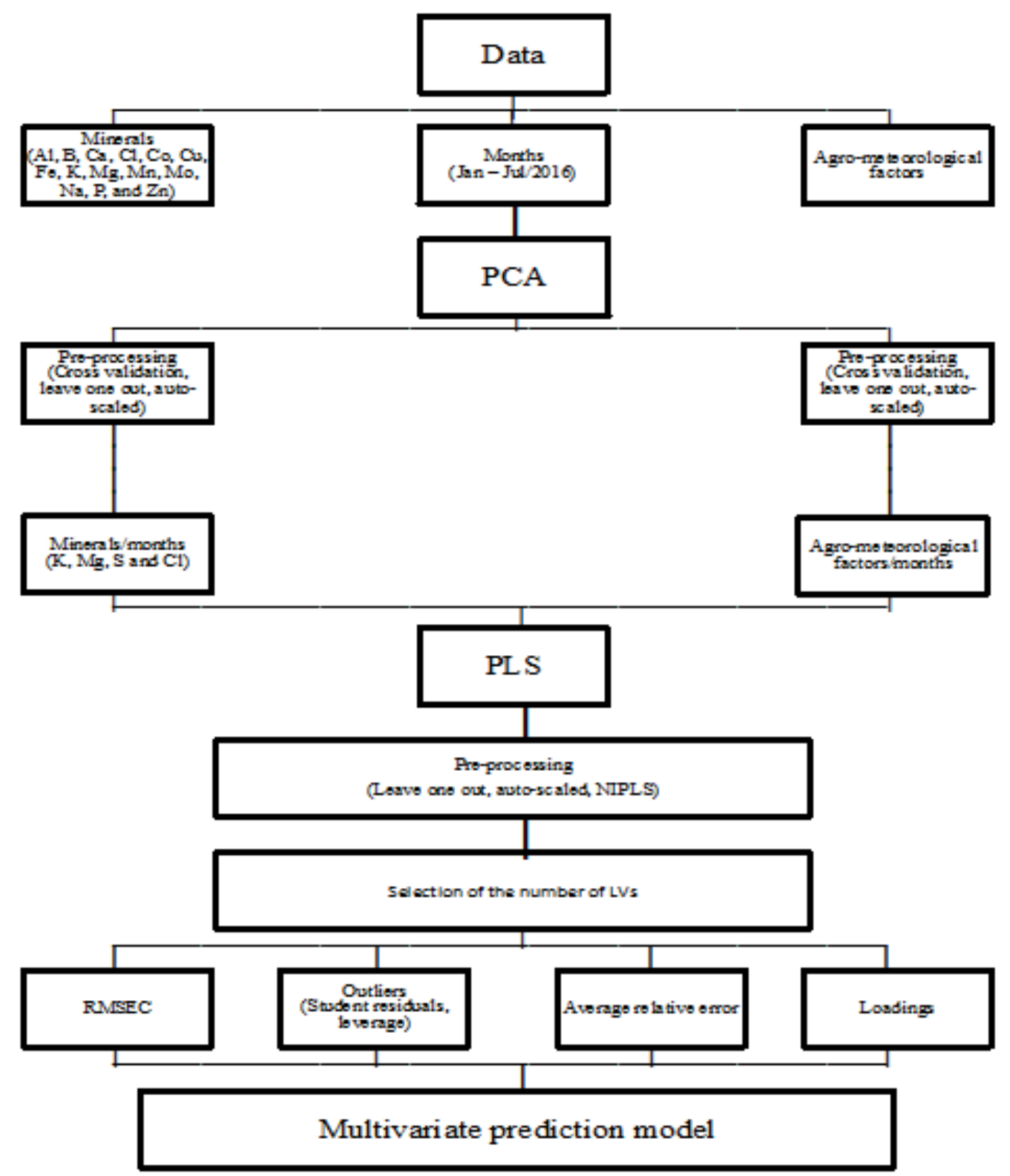

\section{Results}

Principal component analysis of the peach palm heart minerals content

The whole minerals content dataset was used for PCA of peach palm heart throughout the 12 monthtrial period (Table 1). Pre-processing was not used due to the high homogeneity of the samples. The scree plot lists the order number of each axis with the associated value. If this curve shows a stabilization of the eigenvalues, only the axes with order numbers higher than the one that initiates the stabilization can be retained. PCA demonstrated that most of the variance in minerals content data for peach palm heart might be described by only one principal component (PC1: 98.87\%), as shown in Figure 2A. The introduction of additional PCs contributed only with a representation of the details (PC2: $0.97 \%$, PC3: $0.10 \%$ ) in 3 PCs were responsible for representation of $99.94 \%$ of the 
concentration data variance (Figure 2B). Despite of by comparing the predicted concentration for each PC1 explains almost all data, PC2 and PC3 were standard with its true value. This value is presented also used as they present significant details. The cross-validation error (RMSECV) was obtained according to the number of PC (Figure 2C).

Table 1. Mineral values of peach palm heart growing in hillside and lowland over 12 months.

\begin{tabular}{|c|c|c|c|c|c|c|c|c|}
\hline \multirow{2}{*}{ Minerals* } & \multicolumn{2}{|c|}{ January $^{* *}$} & \multicolumn{2}{|c|}{ February $^{* *}$} & \multicolumn{2}{|c|}{$\operatorname{March}^{* *}$} & \multicolumn{2}{|c|}{ April $^{* *}$} \\
\hline & Hillside & Lowland & Hillside & Lowland & Hillside & Lowland & Hillside & Lowland \\
\hline \multirow{2}{*}{ P } & 305.0 & 355.0 & 265.0 & 260.0 & 330.0 & 310.0 & 345.0 & 360.0 \\
\hline & $( \pm 16.2)$ & $( \pm 11.0)$ & $( \pm 15.7)$ & $( \pm 9.5)$ & $( \pm 22.1)$ & $( \pm 22.2)$ & $( \pm 16.3)$ & $( \pm 22.3)$ \\
\hline \multirow{2}{*}{ K } & 2990.0 & 2775.0 & 2200.0 & 2305.0 & 2675.0 & 2370.0 & 2700.0 & 2515.0 \\
\hline & $( \pm 62.9)$ & $( \pm 37.1)$ & $( \pm 83.4)$ & $( \pm 29.3)$ & $( \pm 82.3)$ & $( \pm 27.2)$ & $( \pm 22.6)$ & $( \pm 68.7)$ \\
\hline \multirow{2}{*}{$\mathrm{Ca}$} & 85.0 & 90.0 & 86.0 & 67.0 & 85.0 & 63.0 & 106.0 & 120.0 \\
\hline & $( \pm 1.6)$ & $( \pm 3.9)$ & $( \pm 7.1)$ & $( \pm 2.0)$ & $( \pm 1.7)$ & $( \pm 4.5)$ & $( \pm 4.7)$ & $( \pm 2.3)$ \\
\hline \multirow{2}{*}{$\mathrm{Mg}$} & 445.0 & 483.0 & 345.0 & 353.0 & 460.0 & 416.0 & 528.0 & 572.0 \\
\hline & $( \pm 10.1)$ & $( \pm 8.0)$ & $( \pm 12.2)$ & $( \pm 3.7)$ & $( \pm 8.6)$ & $( \pm 15.4)$ & $( \pm 11.1)$ & $( \pm 15.6)$ \\
\hline \multirow{2}{*}{ S } & 1170.0 & 1230.0 & 1125.0 & 1060.0 & 1210.0 & 1190.0 & 1170.0 & 1080.0 \\
\hline & $( \pm 45.5)$ & $( \pm 19.5)$ & $( \pm 37.8)$ & $( \pm 20.7)$ & $( \pm 28.8)$ & $( \pm 42.6)$ & $( \pm 22.6)$ & $( \pm 42.4)$ \\
\hline \multirow{2}{*}{$\mathrm{Fe}$} & 1.5 & 0.9 & 1.6 & 1.5 & 1.4 & 1.7 & 2.1 & 2.0 \\
\hline & $( \pm 0.0)$ & $( \pm 0.0)$ & $( \pm 0.0)$ & $( \pm 0.0)$ & $( \pm 0.0)$ & $( \pm 0.0)$ & $( \pm 0.0)$ & $( \pm 0.0)$ \\
\hline \multirow{2}{*}{$\mathrm{Mn}$} & 0.4 & 0.4 & 0.5 & 0.8 & 0.6 & 0.4 & 0.5 & 0.5 \\
\hline & $( \pm 0.0)$ & $( \pm 0.0)$ & $( \pm 0.0)$ & $( \pm 0.0)$ & $( \pm 0.0)$ & $( \pm 0.0)$ & $( \pm 0.0)$ & $( \pm 0.0)$ \\
\hline \multirow{2}{*}{$\mathrm{Cu}$} & 0.2 & 0.1 & 0.7 & 0.1 & 0.2 & 1.0 & 1.8 & 1.6 \\
\hline & $( \pm 0.0)$ & $( \pm 0.0)$ & $( \pm 0.0)$ & $( \pm 0.0)$ & $( \pm 0.0)$ & $( \pm 0.0)$ & $( \pm 0.0)$ & $( \pm 0.0)$ \\
\hline \multirow{2}{*}{$\mathrm{Zn}$} & 9.0 & 9.0 & 7.0 & 8.0 & 5.0 & 7.0 & 12.0 & 8.0 \\
\hline & $( \pm 0.2)$ & $( \pm 0.1)$ & $( \pm 0.1)$ & $( \pm 0.1)$ & $( \pm 0.1)$ & $( \pm 0.2)$ & $( \pm 0.1)$ & $( \pm 0.1)$ \\
\hline \multirow{2}{*}{ B } & 9.0 & 5.0 & 8.0 & 8.0 & 10.0 & 6.0 & 4.0 & 7.0 \\
\hline & $( \pm 0.5)$ & $( \pm 0.4)$ & $( \pm 0.7)$ & $( \pm 0.4)$ & $( \pm 0.5)$ & $( \pm 0.6)$ & $( \pm 0.5)$ & $( \pm 0.7)$ \\
\hline \multirow{2}{*}{$\mathrm{Na}$} & 2.0 & 1.0 & 2.0 & 1.0 & 1.0 & 15.0 & 5.0 & 3.0 \\
\hline & $( \pm 0.3)$ & $( \pm 0.1)$ & $( \pm 0.3)$ & $( \pm 0.2)$ & $( \pm 0.3)$ & $( \pm 0.3)$ & $( \pm 0.4)$ & $( \pm 0.4)$ \\
\hline \multirow{2}{*}{$\mathrm{Co}$} & 0.2 & 0.2 & 0.2 & 0.3 & 0.3 & 0.3 & 0.3 & 0.3 \\
\hline & $( \pm 0.0)$ & $( \pm 0.0)$ & $( \pm 0.0)$ & $( \pm 0.0)$ & $( \pm 0.0)$ & $( \pm 0.0)$ & $( \pm 0.0)$ & $( \pm 0.0)$ \\
\hline \multirow{2}{*}{ Mo } & 0.1 & 0.1 & 0.1 & 0.2 & 0.1 & 0.2 & 0.2 & 0.2 \\
\hline & $( \pm 0.0)$ & $( \pm 0.0)$ & $( \pm 0.0)$ & $( \pm 0.0)$ & $( \pm 0.0)$ & $( \pm 0.0)$ & $( \pm 0.0)$ & $( \pm 0.0)$ \\
\hline \multirow{2}{*}{$\mathrm{Cl}$} & 1770.0 & 1860.0 & 1775.0 & 1950.0 & 1500.0 & 1330.0 & 1685.0 & 1685.0 \\
\hline & $( \pm 88.6)$ & $( \pm 66.3)$ & $( \pm 37.7)$ & $( \pm 19.9)$ & $( \pm 95.0)$ & $( \pm 92.8)$ & $( \pm 61.9)$ & $( \pm 49.1)$ \\
\hline
\end{tabular}


continuation

\begin{tabular}{|c|c|c|c|c|c|c|c|c|}
\hline \multirow{2}{*}{ Minerals ${ }^{*}$} & \multicolumn{2}{|c|}{ May $^{* *}$} & \multicolumn{2}{|c|}{ June $^{* *}$} & \multicolumn{2}{|c|}{ July $^{* *}$} & \multicolumn{2}{|c|}{ August ${ }^{* *}$} \\
\hline & Hillside & Lowland & Hillside & Lowland & Hillside & Lowland & Hillside & Lowland \\
\hline \multirow{2}{*}{$P$} & 385.0 & 375.0 & 330.0 & 385.0 & 390.0 & 350.0 & 305 & 290 \\
\hline & $( \pm 24.0)$ & $( \pm 17.2)$ & $( \pm 17.1)$ & $( \pm 19.3)$ & $( \pm 16.4)$ & $( \pm 11.5)$ & $( \pm 16.2)$ & $( \pm 10.4)$ \\
\hline \multirow{2}{*}{ K } & 3220.0 & 2680.0 & 3425.0 & 2835.0 & 2920.0 & 3100.0 & 2410.0 & 2335.0 \\
\hline & $( \pm 26.9)$ & $( \pm 58.5)$ & $( \pm 30.8)$ & $( \pm 23.4)$ & $( \pm 64.6)$ & $( \pm 35.6)$ & $( \pm 84.0)$ & $( \pm 29.3)$ \\
\hline \multirow{2}{*}{$\mathrm{Ca}$} & 110.0 & 76.0 & 133.0 & 130.0 & 95.0 & 110.0 & 145.0 & 131.0 \\
\hline & $( \pm 4.6)$ & $( \pm 4.3)$ & $( \pm 4.2)$ & $( \pm 2.4)$ & $( \pm 1.8)$ & $( \pm 3.8)$ & $( \pm 69.4)$ & $( \pm 1.8)$ \\
\hline \multirow{2}{*}{$\mathrm{Mg}$} & 512.0 & 445.0 & 595.0 & 535.0 & 483.0 & 415.0 & 342.0 & 386.0 \\
\hline & $( \pm 12.1)$ & $( \pm 11.8)$ & $( \pm 7.2)$ & $( \pm 10.6)$ & $( \pm 11.2)$ & $( \pm 8.3)$ & $( \pm 11.7)$ & $( \pm 3.8)$ \\
\hline \multirow{2}{*}{ S } & 1360.0 & 1295.0 & 1170.0 & 1210.0 & 1380.0 & 1255.0 & 1190.0 & 1040.0 \\
\hline & $( \pm 32.1)$ & $( \pm 20.1)$ & $( \pm 28.5)$ & $( \pm 6.4)$ & $( \pm 46.8)$ & $( \pm 18.1)$ & $( \pm 36.9)$ & $( \pm 21.6)$ \\
\hline \multirow{2}{*}{$\mathrm{Fe}$} & 1.6 & 1.0 & 1.2 & 1.4 & 0.7 & 1.3 & 1.0 & 1.1 \\
\hline & $( \pm 0.0)$ & $( \pm 0.0)$ & $( \pm 0.0)$ & $( \pm 0.0)$ & $( \pm 0.0)$ & $( \pm 0.0)$ & $( \pm 0.0)$ & $( \pm 0.0)$ \\
\hline \multirow{2}{*}{ Mn } & 0.4 & 0.2 & 0.4 & 0.6 & 0.3 & 0.6 & 0.3 & 0.1 \\
\hline & $( \pm 0.0)$ & $( \pm 0.0)$ & $( \pm 0.0)$ & $( \pm 0.0)$ & $( \pm 0.0)$ & $( \pm 0.0)$ & $( \pm 0.0)$ & $( \pm 0.0)$ \\
\hline \multirow{2}{*}{$\mathrm{Cu}$} & 1.7 & 0.5 & 0.1 & 1.1 & 0.1 & 0.1 & 0.5 & 0.4 \\
\hline & $( \pm 0.0)$ & $( \pm 0.0)$ & $( \pm 0.0)$ & $( \pm 0.0)$ & $( \pm 0.0)$ & $( \pm 0.0)$ & $( \pm 0.0)$ & $( \pm 0.0)$ \\
\hline \multirow{2}{*}{$\mathrm{Zn}$} & 10.0 & 8.0 & 9.0 & 9.0 & 7.0 & 9.0 & 3.0 & 4.0 \\
\hline & $( \pm 0.1)$ & $( \pm 0.1)$ & $( \pm 0.1)$ & $( \pm 0.1)$ & $( \pm 0.2)$ & $( \pm 0.1)$ & $( \pm 0.1)$ & $( \pm 0.1)$ \\
\hline \multirow{2}{*}{ B } & 6.0 & 6.0 & 6.0 & 7.0 & 7.0 & 9.0 & 8.0 & 9.0 \\
\hline & $( \pm 0.4)$ & $( \pm 0.4)$ & $( \pm 0.6)$ & $( \pm 0.4)$ & $( \pm 0.6)$ & $( \pm 0.4)$ & $( \pm 0.8)$ & $( \pm 0.5)$ \\
\hline \multirow{2}{*}{$\mathrm{Na}$} & 1.0 & 1.0 & 1.0 & 2.0 & 1.0 & 1.0 & 1.0 & 1.0 \\
\hline & $( \pm 0.4)$ & $( \pm 0.4)$ & $( \pm 0.7)$ & $( \pm 0.4)$ & $( \pm 0.3)$ & $( \pm 0.1)$ & $( \pm 0.3)$ & $( \pm 0.2)$ \\
\hline \multirow{2}{*}{ Co } & 0.3 & 0.1 & 0.2 & 0.3 & 0.1 & 0.3 & 0.1 & 0.2 \\
\hline & $( \pm 0.0)$ & $( \pm 0.0)$ & $( \pm 0.0)$ & $( \pm 0.0)$ & $( \pm 0.0)$ & $( \pm 0.0)$ & $( \pm 0.0)$ & $( \pm 0.0)$ \\
\hline \multirow{2}{*}{ Mo } & 0.1 & 0.1 & 0.1 & 0.2 & 0.0 & 0.0 & 0.0 & 0.0 \\
\hline & $( \pm 0.0)$ & $( \pm 0.0)$ & $( \pm 0.0)$ & $( \pm 0.0)$ & $( \pm 0.0)$ & $( \pm 0.0)$ & $( \pm 0.0)$ & $( \pm 0.0)$ \\
\hline \multirow{2}{*}{$\mathrm{Cl}$} & 1420.0 & 1330.0 & 2215.0 & 2305.0 & 1685.0 & 1505.0 & 1330.0 & 1330.0 \\
\hline & $( \pm 32.9)$ & $( \pm 42.6)$ & $( \pm 64.5)$ & $( \pm 84.8)$ & $( \pm 90.3)$ & $( \pm 66.2)$ & $( \pm 38.1)$ & $( \pm 20.1)$ \\
\hline
\end{tabular}


continuation

\begin{tabular}{|c|c|c|c|c|c|c|c|c|}
\hline \multirow{2}{*}{ Minerals* } & \multicolumn{2}{|c|}{ September ${ }^{* *}$} & \multicolumn{2}{|c|}{ October ${ }^{* *}$} & \multicolumn{2}{|c|}{ November $^{* *}$} & \multicolumn{2}{|c|}{ December $^{* *}$} \\
\hline & Hillside & Lowland & Hillside & Lowland & Hillside & Lowland & Hillside & Lowland \\
\hline \multirow{2}{*}{$\mathrm{P}$} & 445.0 & 380.0 & 345.0 & 310.0 & 390.0 & 310.0 & 415.0 & 320.0 \\
\hline & $( \pm 22.1)$ & $( \pm 23.9)$ & $( \pm 15.4)$ & $( \pm 21.6)$ & $( \pm 22.7)$ & $( \pm 18.0)$ & $( \pm 18.1)$ & $( \pm 17.8)$ \\
\hline \multirow{2}{*}{$\mathrm{K}$} & 2875.0 & 3230.0 & 2710.0 & 2470.0 & 2540.0 & 2410.0 & 2675.0 & 2495.0 \\
\hline & $( \pm 82.1)$ & $( \pm 27.9)$ & $( \pm 23.3)$ & $( \pm 68.9)$ & $( \pm 27.4)$ & $( \pm 57.8)$ & $( \pm 32.2)$ & $( \pm 17.2)$ \\
\hline \multirow{2}{*}{$\mathrm{Ca}$} & 120.0 & 119.0 & 104.0 & 73.0 & 103.0 & 107.0 & 103.0 & 59.0 \\
\hline & $( \pm 1.5)$ & $( \pm 4.6)$ & $( \pm 4.8)$ & $( \pm 2.9)$ & $( \pm 4.2)$ & $( \pm 3.4)$ & $( \pm 4.1)$ & $( \pm 1.7)$ \\
\hline \multirow{2}{*}{$\mathrm{Mg}$} & 528.0 & 583.0 & 410.0 & 445.0 & 460.0 & 490.0 & 465.0 & 587.0 \\
\hline & $( \pm 9.2)$ & $( \pm 15.7)$ & $( \pm 11.1)$ & $( \pm 19.2)$ & $( \pm 11.4)$ & $( \pm 11.9)$ & $( \pm 7.4)$ & $( \pm 14.7)$ \\
\hline \multirow{2}{*}{ S } & 1295.0 & 1440.0 & 1170.0 & 1315.0 & 1190.0 & 1145.0 & 1190.0 & 1125.0 \\
\hline & $( \pm 29.9)$ & $( \pm 41.9)$ & $( \pm 22.2)$ & $( \pm 42.0)$ & $( \pm 31.1)$ & $( \pm 19.2)$ & $( \pm 25.2)$ & $( \pm 6.2)$ \\
\hline \multirow{2}{*}{$\mathrm{Fe}$} & 1.7 & 1.2 & 1.4 & 1.0 & 1.5 & 1.2 & 1.9 & 0.8 \\
\hline & $( \pm 0.0)$ & $( \pm 0.0)$ & $( \pm 0.0)$ & $( \pm 0.0)$ & $( \pm 0.0)$ & $( \pm 0.0)$ & $( \pm 0.0)$ & $( \pm 0.0)$ \\
\hline \multirow{2}{*}{$\mathrm{Mn}$} & 0.5 & 0.4 & 0.4 & 0.3 & 0.3 & 0.2 & 0.6 & 0.2 \\
\hline & $( \pm 0.0)$ & $( \pm 0.0)$ & $( \pm 0.0)$ & $( \pm 0.0)$ & $( \pm 0.0)$ & $( \pm 0.0)$ & $( \pm 0.0)$ & $( \pm 0.0)$ \\
\hline \multirow{2}{*}{$\mathrm{Cu}$} & 0.1 & 0.3 & 0.1 & 0.1 & 0.1 & 0.1 & 0.1 & 0.1 \\
\hline & $( \pm 0.0)$ & $( \pm 0.0)$ & $( \pm 0.0)$ & $( \pm 0.0)$ & $( \pm 0.0)$ & $( \pm 0.0)$ & $( \pm 0.0)$ & $( \pm 0.0)$ \\
\hline \multirow{2}{*}{$\mathrm{Zn}$} & 12.0 & 11.0 & 8.0 & 3.0 & 13.0 & 12.0 & 10.0 & 8.0 \\
\hline & $( \pm 0.1)$ & $( \pm 0.2)$ & $( \pm 0.1)$ & $( \pm 0.1)$ & $( \pm 0.1)$ & $( \pm 0.1)$ & $( \pm 0.1)$ & $( \pm 0.1)$ \\
\hline \multirow{2}{*}{ B } & 6.0 & 7.0 & 4.0 & 6.0 & 6.0 & 7.0 & 8.0 & 9.0 \\
\hline & $( \pm 0.5)$ & $( \pm 0.7)$ & $( \pm 0.5)$ & $( \pm 0.9)$ & $( \pm 0.4)$ & $( \pm 0.4)$ & $( \pm 0.8)$ & $( \pm 0.3)$ \\
\hline \multirow{2}{*}{$\mathrm{Na}$} & 1.0 & 1.0 & 1.0 & 1.0 & 1.0 & 1.0 & 1.0 & 1.0 \\
\hline & $( \pm 0.3)$ & $( \pm 0.3)$ & $( \pm 0.4)$ & $( \pm 0.4)$ & $( \pm 0.4)$ & $( \pm 0.3)$ & $( \pm 0.7)$ & $( \pm 0.5)$ \\
\hline \multirow{2}{*}{ Co } & 0.3 & 0.3 & 0.3 & 0.1 & 0.2 & 0.3 & 0.3 & 0.1 \\
\hline & $( \pm 0.0)$ & $( \pm 0.0)$ & $( \pm 0.0)$ & $( \pm 0.0)$ & $( \pm 0.0)$ & $( \pm 0.0)$ & $( \pm 0.0)$ & $( \pm 0.0)$ \\
\hline \multirow{2}{*}{ Mo } & 0.1 & 0.2 & 0.1 & 0.1 & 0.2 & 0.1 & 0.1 & 0.0 \\
\hline & $( \pm 0.0)$ & $( \pm 0.0)$ & $( \pm 0.0)$ & $( \pm 0.0)$ & $( \pm 0.0)$ & $( \pm 0.0)$ & $( \pm 0.0)$ & $( \pm 0.0)$ \\
\hline \multirow{2}{*}{$\mathrm{Cl}$} & 1860.0 & 2480.0 & 1950.0 & 1775.0 & 2215.0 & 1330.0 & 2125.0 & 975.0 \\
\hline & $( \pm 95.5)$ & $( \pm 94.3)$ & $( \pm 61.2)$ & $( \pm 49.1)$ & $( \pm 33.2)$ & $( \pm 42.3)$ & $( \pm 61.2)$ & $( \pm 86.3)$ \\
\hline
\end{tabular}

"ppm. ${ }^{* *} 2016$.

There was a clustering trend of $\mathrm{K}, \mathrm{Mg}, \mathrm{S}$ and $\mathrm{Cl}$ regarding the months of cropping (Figure $3 \mathrm{~A}$ ). The $\mathrm{K}, \mathrm{Mg}$ and $\mathrm{S}$ content of peach palm hearts (on the chart, data 2, 4 and 5), from plants grown on lowland terrain were influenced by agro-meteorological factors in the first half of the year, in months of January (15), March (19), April (21), May (23), July (27); and August (29). Plants grown on hillside terrain were influenced in months of March (20),
May (24), July (28), August (30), November (36), December (38). The $\mathrm{Cl}$ content (14), grown both in lowland and hillside terrain, were influenced in February (17) and the second half of the year by agro-meteorological factors in the months of, June (25), September (31), October (33), November (35), December (37). Plants grown on hillside terrain were influenced in months of January (16), February (18), April (22), June (26), September (32), October 
(34). There was no grouping formation of $\mathrm{P}, \mathrm{Ca}, \mathrm{Fe}$, might have been influenced by other factors not $\mathrm{Mn}, \mathrm{Cu}, \mathrm{Zn}, \mathrm{B}, \mathrm{Na}$, Co and Mo contents of peach described in this study. palm heart in $\mathrm{PC} 1, \mathrm{PC} 2$ and $\mathrm{PC} 3$, so these minerals

Figure 2. Distribution of eigenvalues (scree plot); evolution of the variance captured value as a function of the principal component number; evolution of the RMSECV value and the captured variance as a function of the principal components in the basal of peach palm heart (A, B and C) and agro-meteorological data (D, E and F), respectively.
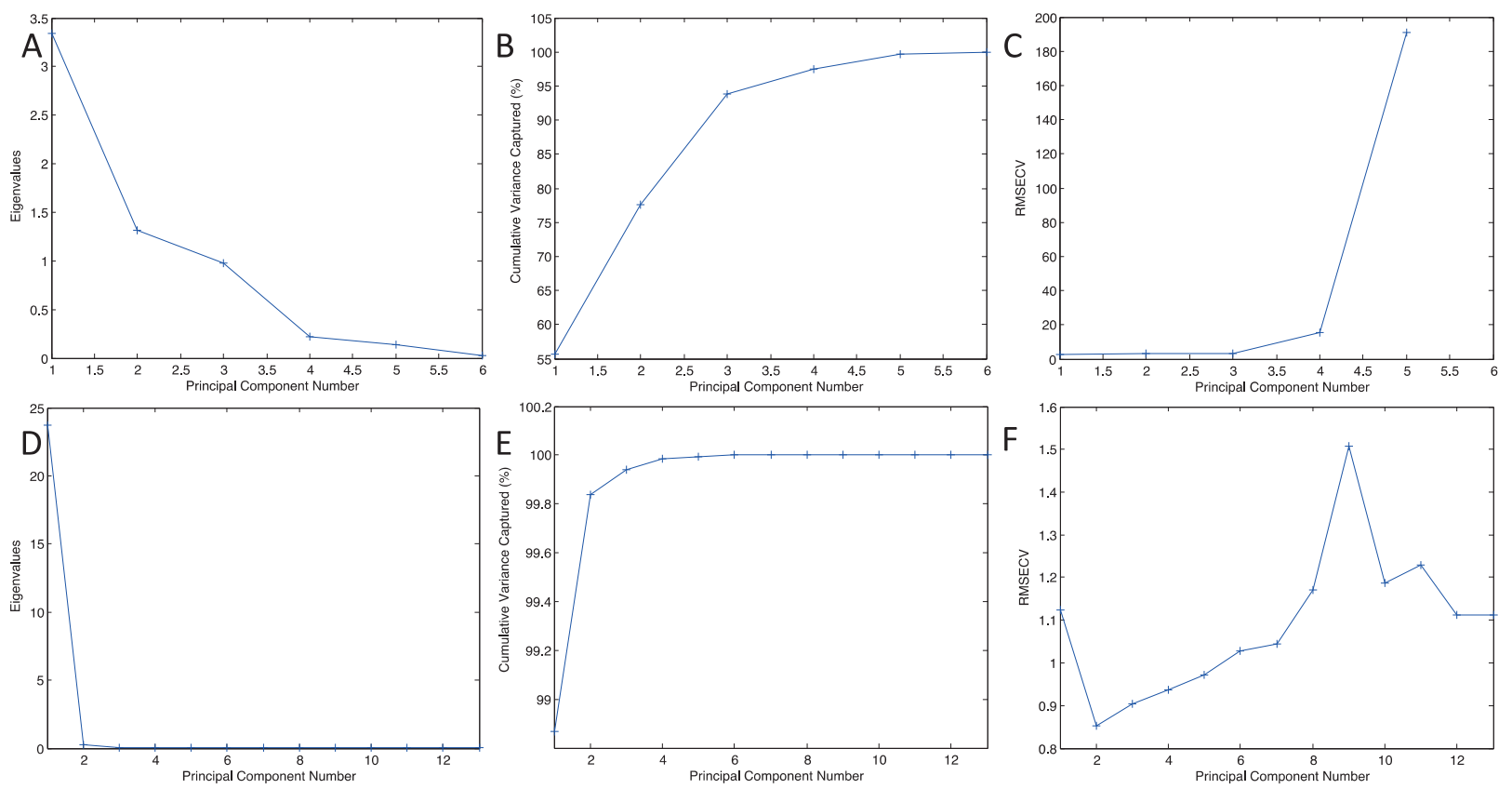

Figure 3. Scores of the principal component analysis performed with different samples in the basal of peach palm hearts $(\mathrm{A})^{*}$ growing in hillside and lowland; and agro-meteorological data $(\mathrm{B})^{* *}$ : PC1 x PC2 x PC3. "Minerals $(1-14)$ and months $(15-38) .{ }^{* *}$ Months $(1-12)$ and agro-meteorological factors $(13-16)$.
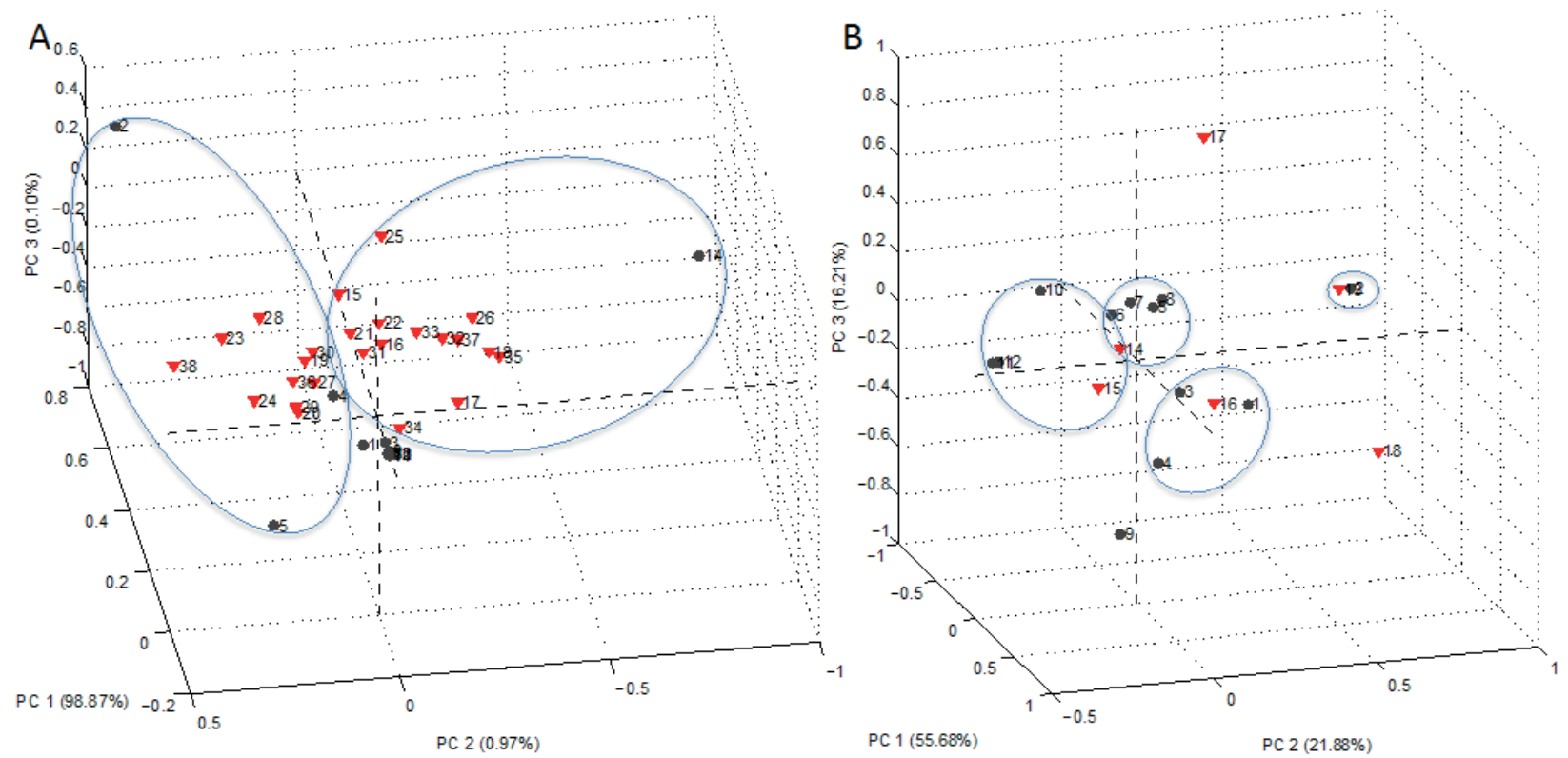

Semina: Ciências Agrárias, Londrina, v. 40, n. 6, suplemento 3, p. 3383-3398, 2019 
Principal component analysis of the agrometeorological data

The entire agro-meteorological dataset was used for the PCA (Table 2). In order to eliminate problems with sample heterogeneity, due to high amplitude between the sampling data, an auto-scaled pre-processing (leave-one-out) was employed. The first Principal Component (PC1) explained 55.68\% of the variation of the agro-meteorological data, while the PC2 and PC3 explained 21.98\% and $16.21 \%$, respectively, of the variation of the agrometeorological data (93.78\%), as shown in Figures 2D and 2E. Despite of the highest error value was obtained with 3 PCs (Figure 2F) and PC1 explained almost all of the variation found in the agrometeorological data; PC2 and PC3 were also used because they present significant details.

Table 2. Agro-meteorological data for the peach palm harvest area.

\begin{tabular}{lcccc}
\hline \multirow{2}{*}{ Month $^{*}$} & Precipitation & Atmospheric pressure & Solar radiation & Temperature \\
\cline { 2 - 5 } & $(\mathrm{mm})$ & $(\mathrm{hPa})$ & $\left(\mathrm{W} \mathrm{m}^{-2}\right)$ & $\left({ }^{\circ} \mathrm{C}\right)$ \\
\hline January & $273.8 \pm 4.04$ & $1010.64 \pm 3.50$ & $1111.0 \pm 1.71$ & $26.66 \pm 1.71$ \\
February & $558.2 \pm 3.11$ & $1010.93 \pm 2.70$ & $1068.0 \pm 1.69$ & $25.63 \pm 1.69$ \\
March & $162.0 \pm 8.93$ & $1013.08 \pm 4.40$ & $1070.0 \pm 2.83$ & $24.99 \pm 2.83$ \\
April & $129.6 \pm 8.23$ & $1012.63 \pm 3.73$ & $910.0 \pm 2.10$ & $25.59 \pm 2.10$ \\
May & $96.4 \pm 12.44$ & $1017.00 \pm 4.18$ & $758.0 \pm 2.23$ & $19.21 \pm 2.23$ \\
June & $19.6 \pm 14.37$ & $1021.89 \pm 2.91$ & $715.0 \pm 2.73$ & $14.08 \pm 2.73$ \\
July & $81.8 \pm 15.88$ & $1017.91 \pm 2.63$ & $698.0 \pm 1.65$ & $16.57 \pm 1.65$ \\
August & $132.0 \pm 25.87$ & $1016.80 \pm 2.62$ & $888.0 \pm 1.66$ & $17.60 \pm 1.66$ \\
September & $102.4 \pm 11.00$ & $1016.88 \pm 3.94$ & $943.0 \pm 1.36$ & $19.37 \pm 1.36$ \\
October & $191.2 \pm 10.16$ & $1014.40 \pm 3.60$ & $1008.0 \pm 3.84$ & $20.55 \pm 3.84$ \\
November & $90.8 \pm 4.38$ & $1012.63 \pm 3.92$ & $1085.0 \pm 0.9$ & $21.85 \pm 0.9$ \\
December & $99.0 \pm 2.62$ & $1010.30 \pm 3.76$ & $1206.0 \pm 0.88$ & $24.33 \pm 0.88$ \\
\hline
\end{tabular}

*2016.

The months of January (1), March (3) and April (4) had significant average temperature (16), as shown in Figure 3B. The month of February (2) had significant atmospheric pressure (13). The months of May (5), June (6), July (7) and August (8) had significant atmospheric pressure (14). The months of October (10), November (11) and December (12) had significant average solar radiation (15). The months of January (1), March (3), and April (4) September (9) had significant had significant average temperature (16). There was no grouping formation of relative humidity (17) and wind speed (18) in PC1, PC2 and PC3, so these agrometeorological data might have been influenced by other factors not described in this study.
Therefore, the data described in this work shows that $\mathrm{K}, \mathrm{Mg}, \mathrm{Cl}$ and $\mathrm{S}$ content in the basal portion of peach palm hearts were mainly influenced by temperature, rain precipitation, atmospheric pressure and average solar radiation.

\section{Calibration and validation of Partial Least Squares (PLS)-based predictive models}

Partial least squares regression was used to build multivariate calibration models. They were developed to predict minerals content values for the peach palm heart from agro-meteorological factors. Several models were developed using different types of pre-processing techniques and different 
number of latent variables (LVs). Normally, the first decision that must be made in the multivariate modelling process is represented by the selection of the number of LVs. In this study, the adopted criterion corresponded to the minimization of forecast error in the validation process (leave-oneout system) (STETS et al., 2015). The number of latent variables in which there is no appreciable variation in the RMSEC value is used to determine the number of latent variables to be used in the model (SOUZA et al., 2013).

For $\mathrm{K}, \mathrm{Mg}, \mathrm{S}$ and $\mathrm{Cl}$ content, the best predictive capacity was achieved using a model developed with 2 LVs and auto-scaled pre-processing. The use of 2 LV implied significant reduction of this prediction error, whereas the introduction of new variables increased a little bit this parameter. The second latent variable (LV2) explained 95.46\%, 95.57\%, 93.18\% and $88.30 \%$ of the variation of the $\mathrm{K}, \mathrm{Mg}, \mathrm{S}$ and $\mathrm{Cl}$ content, respectively. The use of a high number of LVs may represent an overfitting of the model, which, in general, undermines the predictability of new samples (MALUF et al., 2010). In this study, the smallest prediction errors were provided by the processing of data auto-scaled (leave one out preprocessing). This model provided a good agreement between real and predicted values. The relative prediction errors were $0.62 \%, 4.94 \%, 4.53 \%$ and $8.32 \%$ for $\mathrm{K}, \mathrm{Mg}, \mathrm{S}$ and $\mathrm{Cl}$ content, respectively (Equations 1, 2, 3 and 4, respectively).

$\mathrm{K}=-0.44631 \beta_{0}+0.05888 \beta_{l}-0.22928 \beta_{2}-0.018946 \beta_{3}$ (Equation 1)

$\mathrm{Mg}=-0.89197 \beta_{0}-0.016136 \beta_{1}-0.16484 \beta_{2}-0.45642 \beta_{3}$ (Equation 2)
$\mathrm{S}=-0.48648 \beta_{0}-0.27205 \beta_{1}-0.50395 \beta_{2}+0.1113 \beta_{3}$

(Equation 3)

$\mathrm{Cl}=0.67077 \beta_{0}+0.83731 \beta_{1}+0.58406 \beta_{2}-0.46258 \beta_{3}$

(Equation 4)

where $\beta_{0}, \beta_{1}, \beta_{2}$ e $\beta_{3}$ represent the equation coefficients: rain precipitation $(\mathrm{mm})$, atmospheric pressure $(\mathrm{hPa})$, solar radiation $\left(\mathrm{W} \mathrm{m}^{-2}\right)$ air temperature $\left({ }^{\circ} \mathrm{C}\right)$.

An important aspect for the optimization of calibration models is to examine the presence of anomalous samples (outliers). Outliers are highvalue samples of leverage and studentized residuals, which assign significant detrimental effects to the model, and should be removed from the collected data (PEDRO; FERREIRA, 2005). In the process of PLS, this verification is performed through the evaluation of leverage, a parameter associated with the influence of each sample in the modelling, as well as studentized residuals (MAZUR et al., 2014). A threshold value of the leverage of 0.75 for $\mathrm{K}$, $\mathrm{Mg}, \mathrm{S}$ and $\mathrm{Cl}$ content (Figures 4A, 4B, 4C and 4D, respectively), was determined by $3 \mathrm{LV} \mathrm{n}^{-1}$ (where "LV" is the number of latent variables used in modelling and " $n$ " is the total number of samples), while the threshold value for the studentized residuals was \pm 2.5 (95\% confidence level). Sample 2 (Figures 4A and 4B), present a residue above the critical value, but it was not considered an atypical sample because it had an influence close to the more rigorous critical value (FERREIRA, 2015). Based on this assessment, it was possible to show the absence of anomalies in the calibration set. 
Figure 4. Leverage vs. studentized residues chart of content of $\mathrm{K}(\mathrm{A}), \mathrm{Mg}(\mathrm{B}), \mathrm{S}(\mathrm{C})$ and $\mathrm{Cl}$ (D) in the basal peach palm heart.
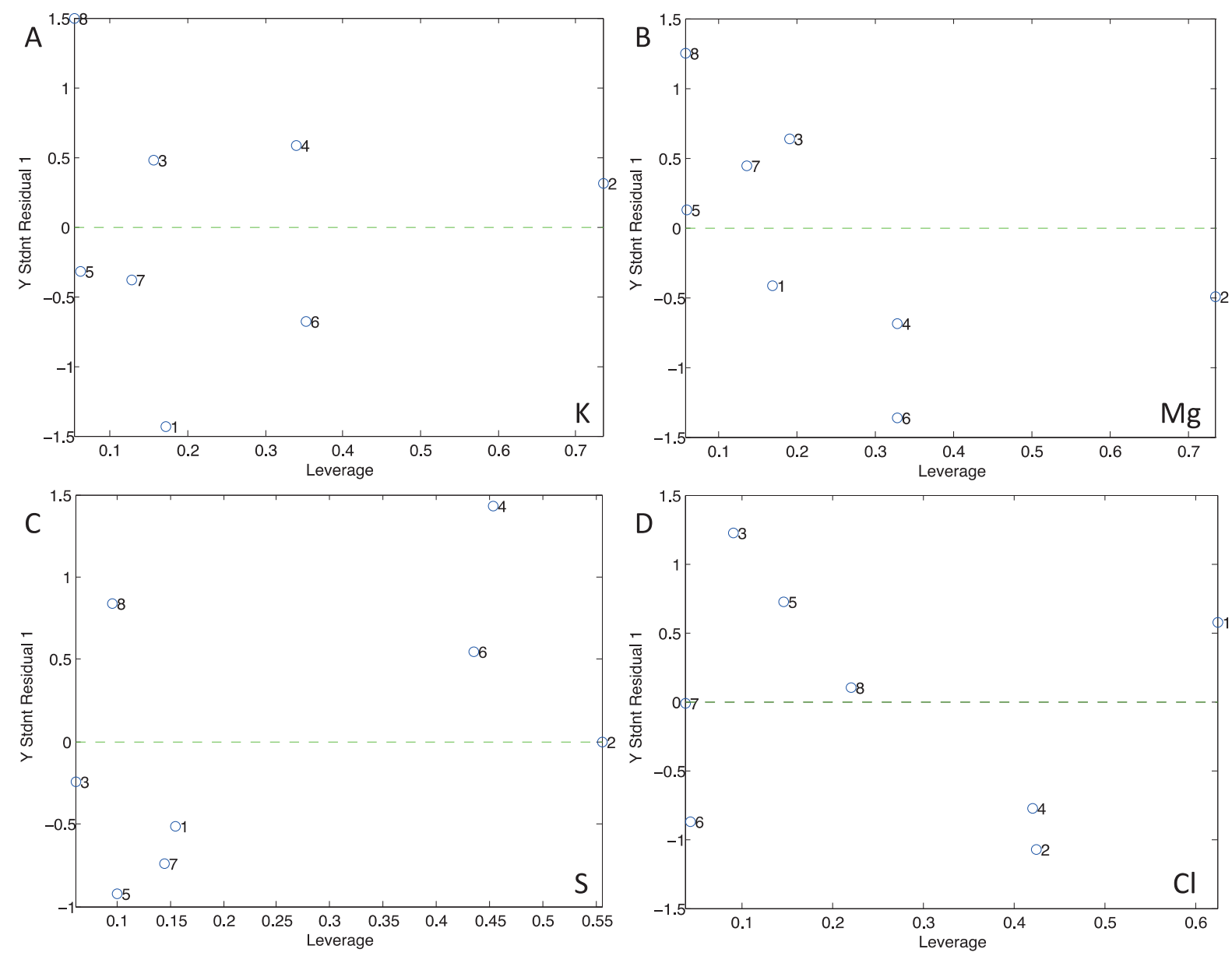

\section{Discussion}

Interactions between peach palm crops and climate were taken into account as confirmed by a multivariate analysis. Furthermore, the model allowed a systematic comparison of cropping minerals content with agro-meteorological factors. Accordingly, results of the present study are especially relevant, in which, the sensitivity of crop mineral to rain precipitation and air temperature variation constitutes the main variable for the change in minerals content. The results indicate a mean error on the order of $4.60 \%$ relative to the atomic absorption spectrophotometry method used as the reference $(1.0-5.0 \%)$. It is noteworthy that, even with an average deviation on the order of $0.40 \%$, the multivariate predictive model provided

differences of up to $8.32 \%$, probably due to the already mentioned heterogeneity of the samples. Thus, obtaining maximum prediction errors of this magnitude is consistent with the results obtained by atomic absorption spectrophotometry. According to Ferreira (2015), the calibration models are satisfactory when the mean relative errors in the concentrations measured by the reference methods are in the range of $\pm 5 \%$, reliable up to $\pm 10 \%$.

According to the data and information showed in the present article, the most influence factors in $\mathrm{K}$ content prediction model were the rain precipitation and the solar radiation $(-0.45$ and -0.23 times, respectively), followed by the atmospheric pressure and air temperature, respectively, as show in Figure $5 \mathrm{~A}$. A lack of $\mathrm{K}$ results in the accumulation of non- 
fully metabolised nitrogen compounds, also essential for oxidative phosphorylation and photosynthetic. For $\mathrm{Mg}$ content, the principal influences in prediction model were the air temperature (-0.89 times), atmospheric pressure (0.46 times), respectively (Figure 5B). Above a particular temperature, the input of nutrients cannot maintain the same concentration with the exit of nutrients, so the average absorption of nutrients begins to fall (EPSTEIN; BLOOM, 2006). Mg is considered mobile and concentrated in the soft part of the plant (basal portion of peach palm heart), where new cells are produced for growth. This explains the higher concentrations in the period of lower precipitation, that is, in this period the plant growth is lower, when compared to the period of higher precipitation, where the number of leaves tends to increase. There were significant differences among precipitation periods for $\mathrm{Ca}$ and $\mathrm{Mg}$ content, with the latter inversely proportional $(3: 1)$ to what is usually found in peach palm leaves and soil (2:1). The $\mathrm{S}$ content was influenced by the solar radiation ( -0.50 times) and rain precipitation (-0.49 times), respectively (Figure 5C). The main agro-meteorological factor that influenced the $\mathrm{Cl}$ content was solar radiation and the rain precipitation $(0.84$ and 0.67 times, respectively) (Figure 5D). $\mathrm{K}$ and $\mathrm{Cl}$ content were highest (3425 ppm and 2485 ppm, respectively) in all collecting periods. In general, it was found that the period of lower precipitation showed the best results in terms of mineral concentration in the basal portion of peach palm hearts.

Figure 5. Loadings chart of the multivariate predictive model of content of $\mathrm{K}(\mathrm{A}), \mathrm{Mg}(\mathrm{B}), \mathrm{S}(\mathrm{C})$ and $\mathrm{Cl}(\mathrm{D})$ in the basal peach palm heart.
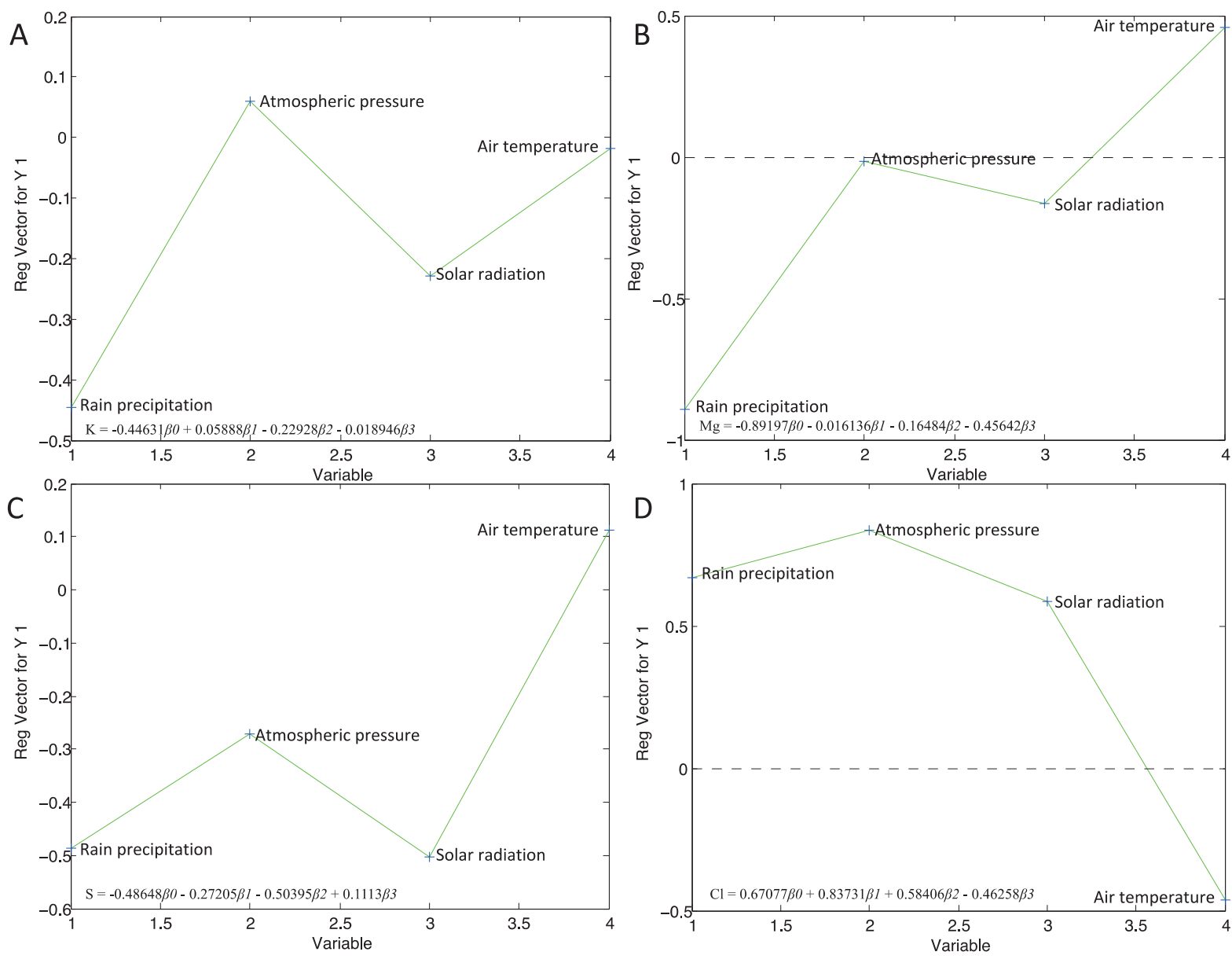
Multivariate analysis used in this work allowed the creation of a highly precise predictive model for the $\mathrm{K}, \mathrm{Mg}, \mathrm{S}$ and $\mathrm{Cl}$ minerals contents in the basal portion of palm hearts from local agrometeorological data. This model can help on the identification of new geographical regions suitable for the establishment of new peach palm crops aimed at the production of palm hearts. Besides, it helps to understand the effect of the climate in the mineral composition of the plant. The proposed approach can be also used for climate change studies, providing a robust framework to assess the impact of climate change on crops. Therefore, it is highly likely that future increases in rain precipitation and air temperature due to the enhanced greenhouse effect would have negative impacts on future peach palms crops in the Latin America. This is in agreement with the findings of many studies in which negative impacts of future warming on the yields of several major food crops have been shown at the global scales (LOBELL; GOURDJI, 2012; TEIXEIRA et al., 2013). As most of the published studies have focused on major food crops of global importance, to our knowledge, the present work constitutes the first published report on the sensitivity of peach palm minerals content to seasonal warming across a rain precipitation and air temperature. The mathematical model can predict in the future or verify in the past whether the nutritional status of the plant will be / was deficient or satisfactory in a given element as a function of the climate. This is the first time in which multivariate analysis is used to generate models to predict minerals concentration in palm hearts, quantifying the intensity of the climate in the concentration of minerals.

\section{Conclusion}

The use of principal component analysis (PCA) allowed the discrimination of peach palm samples according to the agro-meteorological factors. The use of partial least squares (PLS) regression allowed the development, by the first time, of a mathematical model to predict peach palm heart minerals content $(\mathrm{K}, \mathrm{Mg}, \mathrm{S}$ and $\mathrm{Cl})$ and quantifies numerically the intensity of the climate in the concentration of minerals, with a mean relative error of $4.60 \%$. According to the data and information reviewed in the present article, the factors that most influence the minerals content were the rain precipitation and solar radiation. Since the traditional mineral analysis of peach palm hearts typically presents low repeatability and generate large amounts of waste, the use of an alternative method for minerals content prediction, which does not involve sample preparation, presents a series of advantages, including cost and processing time reduction and elimination of chemical waste.

\section{Acknowledgments}

This work was supported by National Council for the Improvement of Higher Education (CAPES) and Institute of Technical Assistance and Rural Extension of Paraná (EMATER-PR).

\section{References}

ASSOCIATION OF OFFICIAL ANALYTICAL CHEMIST - AOAC. Official Methods of Analysis of the Association of Official Analytical Chemist. Gaithersburg: AOAC International, 2010.

BATAGIN-PIOTTO, K. D.; ALMEIDA, C. V. D. E.; PIOTTO, F. A.; ALMEIDA, M. D. E. Anatomical analysis of peach palm (Bactris gasipaes) leaves cultivated in vitro, ex vitro and in vivo. Brazilian Journal of Botany, São Paulo, v. 35, n. 1, p. 71-78, 2012. DOI: 10.1590/ S0100-84042012000100008

CHUNTHABUREE, S.; DONGSANSUK, A.; SANITCHON, J.; PATTANAGUL, W.; THEERAKULPISUT, P. Physiological and biochemical parameters for evaluation and clustering of rice cultivars differing in salt tolerance at seedling stage. Saudi Journal of Biological Sciences, Riyadh, v. 23, n. 4, p. 467-477, 2016. DOI: 10.1016/j.sjbs.2015.05.013

EMPRESA BRASILEIRA DE PESQUISA AGROPECUÁRIA - EMBRAPA. Sistema Brasileiro de Classificação de Solos. 3. ed. rev e ampl. Brasília: EMBRAPA Produção de Informação, 2013. 353 p. 
EPSTEIN, E.; BLOOM, A. J. Nutrição mineral de plantas. 3. ed. Rio de Janeiro: Planta, 2006. 404 p.

FERREIRA, M. M. C. Quimiometria: conceitos, métodos e aplicações. Campinas: UNICAMP, 2015. 496 p.

FRIZON, N. T.; OLIVEIRA, G. A.; PERUSSELLO, C. A.; PERALTA-ZAMORA, P. G.; CAMLOFSKI, A. M. O.; ROSSA, U. B.; HOFFMANN-RIBANI, R. Determination of total phenolic compounds in yerba mate (Ilex paraguariensis) combining near infrared spectroscopy (NIR) and multivariate analysis. LWT Food Science and Technology, Athens v. 60, n. 2, p. 795801, 2015. DOI: 10.1016/j.lwt.2014.10.030

GALDINO, N. O.; CLEMENTE, E. Palm heart (Bactris gasipaes Kunth): mineral composition and kinetics of oxidative enzymes. Ciência e Tecnologia de Alimentos, Campinas, v. 28, n. 1, p. 540-544, 2008.

HERNÁNDEZ-UGALDE， J. A.; MORA-URPÍ, J.; ROCHA, O. J. Genetic relationships among wild and cultivated populations of peach palm (Bactris gasipaes Kunth, Palmae): evidence for multiple independent domestication events. Genetic Resources and Crop Evolution, Gatersleben, v. 58, n. 4, p. 571-583, 2011. DOI: $10.1007 / \mathrm{s} 10722-010-9600-6$

KULCHETSCKI, L.; CHAIMSOHN, F. P.; GARDINGO, J. R. Palmito pupunha (Bactris gasipaes Kunth): a espécie, cultura, manejo agronômico, usos e processamentos. Ponta Grossa: Editora UEPG, 2001. $148 \mathrm{p}$.

LOBELL, D. B.; GOURDJI, S. M. The influence of climate change on global crop productivity. Plant Physiology, Glasgow, v. 160, n. 4, p. 1686-1697, 2012. DOI: $10.1104 /$ pp.112.208298

MALUF, D. F.; PONTAROLO, R.; CORDEIRO, G. A.; NAGATA, N.; PERALTA-ZAMORA, P. Determinação de sibutramina em formas farmacêuticas através de espectroscopia no infravermelho com refletância difusa e métodos de calibração multivariada. Química Nova, São Paulo, v. 33, n. 3, p. 649-652, 2010.

MAZUR, L.; PERALTA-ZAMORA, P.; DEMCZUK, B.; RIBANI, R. H. Application of multivariate calibration and NIR spectroscopy for the quantification of methylxanthines in yerba mate (Ilex paraguariensis). Journal of Food Composition and Analalysis, Beltsville, v. 35, n. 2, p. 55-60, 2014. DOI: 10.1016/j.jfca.2014.04.005

NEVES, E. J. M.; SANTOS, A. F. dos. Produção de pupunheira (Bactris gasipaes) para palmito sob diferentes espaçamentos, no litoral do Estado do Paraná. Pesquisa Florestal Brasileira, Colombo, v. 56, n. 1, p. 87-95, 2008.

NEVES, E. J. M.; SANTOS, Á. F. dos; RODHIGHERI, H. R.; BELLETTINI, S.; TESSMANN, D. J. Cultivo da pupunheira para palmito nas regiões sudeste e sul do Brasil. Colombo: EMBRAPA Florestas, 2007. (Circular técnica, 143).

OLIVEIRA, G. A.; BUREAU, S.; RENARD, C. M. G. C.; PEREIRA-NETTO, A. B.; CASTILHOS, F. Comparison of NIRS approach for prediction of internal quality traits in three fruit species. Food Chemistry, Reading, v. 143, n. 15 , p. 223-230, 2014. DOI: 10.1016/j. foodchem.2013.07.122

PEDRO, A. M. K.; FERREIRA, M. M. C. Non destructive determination of solids and carotenoids in tomato products by near-infrared spectroscopy and multivariate calibration. Analytical Chemistry, Washington, v. 77, n. 8, p. 2505-2511, 2005. DOI: 10.1021/ac048651r

PENTEADO JÚNIOR, J. F.; SANTOS, A. F. dos; NEVES, E. J. M. Aspectos do agronegócio do palmito pupunha no Brasil. Colombo: EMBRAPA Florestas, 2014. 21 p. (Comunicado técnico, 275).

RAUPP, D. S.; CHAIMSOHN, F. P. O envase de palmito de pupunha em vidro. In: KULCHETESCKI, L.; CAMISON, F. P.; GARDINGO, J. R. Palmito pupunha (Bactris gasipaes Kunth): a espécie, cultura, manejo agronômico, usos e processamentos. Ponta Grossa: Editora UEPG, 2001. p. 105-118.

SOUZA, A. M.; BREITKREITZ, M. C.; FILGUEIRAS, P. R.; ROHWEDDER, J. J. R.; POPPI, R. J. Experimento didático de quimiometria para calibração multivariada na determinação de paracetamol em comprimidos comerciais utilizando espectroscopia no infravermelho próximo: um tutorial, Parte II. Química Nova, São Paulo, v. 36 , n. 7 , p. $1057-1065,2013$. DOI: 10.1590/S010040422013000700022

STETS, S.; SILVA, B. D. da; TAVARES, T. M.; CORDEIRO, G. A.; NAGATA, N.; PESSOA, C. A.; PERALTA-ZAMORA, P. Sistemas alternativos de calibração para determinação espectrofotométrica simultânea de espécies com interferência espectral. Química Nova, São Paulo, v. 38, n. 9, p. 1226-1231, 2015. DOI: 10.5935/0100-4042.20150141

TEIXEIRA, E. I.; FISCHER, G.; VAN VELTHUIZEN, H.; WALTER, C.; EWERT, F. Global hot-spots of heat stress on agricultural crops due to climate change. Agricultural and Forest Meteorology, New Haven, v. 170, n. 15, p. 206-215, 2013. DOI: 10.1016/j.agrformet.2011.09.002

XIE, L. J.; YING, Y. B.; YING, T. J. Quantification of chlorophyll content and classification of non transgenic and transgenic tomato leaves using visible/near infrared diffuse reflectance spectroscopy. Journal of Agriculture and Food Chemistry, Reading, v. 55, n. 12, p. 4645-4650, 2007. DOI: $10.1021 /$ jf063664m 
